\title{
Effect of student engagement on multimedia-assisted instruction
}

\author{
Hsiu-Ping Yueh
}

Department of Bio-Industry Communication and Development

National Taiwan University, Taiwan

E-mail: yueh@ntu.edu.tw

\section{Weijane Lin*}

Department of Library and Information Science

National Taiwan University, Taiwan

E-mail: vjlin@ntu.edu.tw

\section{Jo-Yi Huang}

Walsin Lihwa Corporation , Taiwan

E-mail: r95630006@ntu.edu.tw

\section{Horn-Jiunn Sheen}

Institute of Applied Mechanics

National Taiwan University, Taiwan

E-mail: sheenh@ntu.edu.tw

*Corresponding author

\begin{abstract}
This study applied multimedia in a general engineering and technology course in Taiwan and evaluated the effectiveness of multimediaassisted instruction and learning. The course presented trends in technological development and the achievements of Taiwanese industries and research institutes from a historical perspective, and overviewed the technology industries and industrial transformation development in Taiwan. The course units adopted multimedia to support class teaching and student learning, and a survey was conducted to collect students' attitudes and perception toward multimedia-assisted instruction and learning in the course. Research data were collected from 45 male and 9 female students with varied academic and cultural backgrounds. Results showed that multimedia videos help raise students' awareness of learning issues, improve their understanding of content, and increase the depth of their learning. Almost all students liked the approach of using multimedia to assist teaching and learning, preferring this approach over traditional lecture-based instruction. They also would recommend this course to their peers. This study also found that the degree of students' engagement caused variance in the students' perception of multimedia helpfulness in assisting their learning. Finally, this study further proposes suggestions in both design and research on applications of multimedia-enhanced learning in engineering and technology education.
\end{abstract}

Keywords: Learning engagement; Multimedia-assisted instruction; Engineering education; Technology education 
Biographical notes: Hsiu-Ping Yueh is Professor and Chair in the Department of Bio-Industry Communication and Development at National Taiwan University. She is the establisher of Educational Technology Group that is the first professional team to support faculty's use of ICT in teaching and learning in Taiwan universities. Her research interests include cognitive science, learning technology and human resource development.

Weijane Lin is Assistant Professor in the Department of Library and Information Science at National Taiwan University. Her research focuses on the multimedia support to assist human performance in cognitive tasks.

Jo-Yi Huang received her master degree from the Department of Bio-Industry Communication and Development in 2008. She is currently an Administer at Walsin Lihwa Corporation.

Horn-Jiunn Sheen is Professor in the Institute of Applied Mechanics at National Taiwan University. He was the Director of Centre for Teacher Education in National Taiwan University from 2002 to 2004, and has been dedicated to engineering education for a long time. He currently focuses on the research fields of software engineering, nanotechnology and optical instrument system.

\section{Introduction}

In an era of unprecedented technological advancement, engineering practice has been continuing to evolve, but engineering education has not changed appreciably (Lang, Cruse, McVey, \& McMasters, 1999). The Accreditation Board for Engineering and Technology (ABET) Engineering Criteria 2000, which was fully implemented in 2001, emphasizes outcomes over process, and provides an opportunity for stakeholders to help universities define educational goals and objectives and design a curriculum to meet the desired outcomes of advances in technology (Lang et al., 1999). Engineering education, which consists of science and mathematics based-subjects, is content-centered and design-oriented (Bourne, Harris, \& Mayadas, 2005), and therefore the content of engineering education should change along with the developments in technology and industry. A general engineering education defines technology and the role it plays in society, develops students' problem-solving skills, and introduces students to a sequential design process that instills in them the ability to question a process or procedure. The goals of a general engineering education are designed to enable all students, even those who may not possess engineering training backgrounds, to adapt to the changing technological society of today and tomorrow (Mahajan, McDonald, \& Walworth, 1996). For a general engineering education course, it is not easy for one teacher to prepare various materials to present different perspectives of engineering research and development to the class; on the other hand, in a scientific academic field, it is also hard for an engineering student to master all skills or knowledge domains. Therefore, having a variety of resources for main instruction to complement class learning is of special importance in a general engineering education.

To advance industrial development, the government of Taiwan established the National Applied Research Laboratories (NARL) in 2003, with the goals of establishing $\mathrm{R} \& \mathrm{D}$ platforms, assisting academic research, promoting frontier science and technology, and fostering high-tech human resources in Taiwan. It further produced videos to 
introduce advanced science and technology in Taiwan, such as circuit-related industries, the display industry, the computer and information technology industry, nano and biomedical technology, agriculture and ecological research, and traditional industry transformation development in Taiwan. The NARL video platform has become an online educational resource database that engineering educators can adopt into their daily educational practice. To full utilize these resources in a general engineering and technology education course entitled "Scientific Taiwan", offered in a research university in Northern Taiwan, the researchers, who were also instructors, modified and integrated these open resources provided by NARL into the course website, and demonstrated them in class teaching. To verify the effectiveness of this implementation, the purposes of this study are as follows: (1) to integrate the multimedia video releases from NARL into the instructors' teaching in the general engineering and technology education classroom to provide the students with a basic understanding of technological innovation and development in Taiwan; (2) to investigate the effectiveness of applying multimedia materials in assisting instruction and learning in a general engineering education course; and (3) to examine whether students' learning engagement in watching multimedia videos after class has an impact on their attitudes toward multimedia-assisted learning.

\section{Literature review}

\subsection{Multimedia-assisted instruction and learning in engineering education}

Multimedia teaching integrates verbal material, such as printed and spoken text, and visual material, such as pictures, graphs, photos, and dynamic graphics (Mayer, 2001). Specifically video as a multimedia application has been viewed as powerful narrative visualization to be of benefit in teaching and learning in various disciplines including engineering, management science, physical, medical and science education (Garrison, 2001; Marx \& Frost, 1998; Mitchell, 2001; Palmer, 2007; Shephard, 2003). In educational settings, including engineering education, multimedia presentations could provide variety to lesson planning, and facilitate instruction with better visualization and representation (Shephard, 2003; Teo \& Chai, 2009). However, it does not easily and directly support active learning and to identify how to use multimedia-assisted instruction (MAI) effectively is a focus of many experts, professionals, and lecturers (Laurillard, 2002; Sung \& Mayer, 2012).

Previous engineering education researchers have investigated effective teaching styles to fit different learning styles, and the relationships of the two types of styles, in order to find a better way to employ multimedia learning in engineering education. Multimedia approaches have been proved to have the potential to create a high-quality learning environment. Along with the rapid advances in technology, it becomes easier for instructors to access and apply multimedia to assist their teaching of engineering topics, and cases are well documented such as nanotechnology (Wishart \& Blease, 1999), biotechnology engineering (Mutharasan, Magee, Wheatley, \& Lee, 1997), circuit and electronic engineering (Maby, Carlson, Connor, Jennings, \& Schoch, 1997; Schodorf, Yoder, \& McClellan, 1996; Giannotti \& Galletti, 1996; Höhne \& Henkel, 2004; Nortcliffe \& Middleton, 2008; Hunt, Howard, Kirk, Ash, \& Tyrrell, , 2001), computer and information science, mechanical engineering, civil engineering (Kartam \& AlReshaid, 2002), manufacturing education (Raju, Sankarz, \& Xue, 2004), mechatronics (Kikuchi \& Kenjo, 1996), mathematical education (Bringslid, 1999), and environmental engineering (Badran, 1995; Boman \& Olsson, 1996). The advent of multimedia with hypertext, interactive simulations, and animation systems has forged an effective 
information delivery environment with the power of creating interactive laboratories and classrooms (Bengu \& Swart, 1996).

Researchers have applied multimedia in educational contexts and found that it enabled them to choose from a range of media elements to convey a particular message (Cairncross \& Mannion, 1999). The various forms of multimedia, such as videotapes (Mutharasan et al., 1997), multimedia materials on CD-ROM (Boman \& Olsson, 1996), digital audio streams (Nortcliffe \& Middleton, 2008), multimedia instructional software (Kikuchi \& Kenjo, 1996; Schodorf, Yoder, \& McClellan, 1996), web-based multimedia materials (Kartam \& Al-Reshaid, 2002; Raju, Sankarz, \& Xue, 2004; Bringslid, 1999; Badran, 1995), multimedia courseware (Giannotti \& Galletti, 1996), and even the programmable multimedia systems (Höhne \& Henkel, 2004), can meet different needs in practice. Previous studies have suggested that multimedia-assisted instruction can help teachers construct a coherent mental representation from presented materials (Mayer, 2001; Mutharasan et al., 1997), illustrate spatial relationships (Sutcliffe \& Faraday, 1994), and present information appropriately for different kinds of learners (Cairncross \& Mannion, 1999). It can also increase the depth of students' learning of specific issues (Höhne \& Henkel, 2004; Cairncross \& Mannion, 1999; Yueh \& Sheen, 2009), and engage students in a way that static material does not (Cairncross \& Mannion, 1999). Accompanied with good course design, it can also allow the instructor to quickly assess the effectiveness of a particular presentation (Maby et al., 1997).

Felder and Silverman (1988) categorized learners by the way they receive information into three dimensions: visual learners, verbal learners, and kinaesthetic learners. They also suggest that instructors use graphical materials to accompany verbal materials in their class presentations to help both visual and verbal learners to learn in engineering courses. Using multimedia presentations to assist students' learning in engineering can help learners to recognize and retain the presented material (Cairncross \& Mannion, 1999). But it also needs to improve their development in problem-solving (Höhne \& Henkel, 2004) and decision-making (Raju, Sankarz, \& Xue, 2004) with consideration of different learning styles and capabilities (Maby et al., 1997). Researchers have found that higher motivation (Giannotti \& Galletti, 1996; Höhne \& Henkel, 2004; Kikuchi \& Kenjo, 1996) toward learning could lead to greater ongoing engagement when multimedia materials are used to assist learning (Nortcliffe \& Middleton, 2008). Moreover, the better accessibility of multimedia-assisted instruction could also maintain and provide learning resources (Badran, 1995) for students to study at any time, place, and pace suited to the learner (Schodorf, Yoder, \& McClellan, 1996; Kartam \& AlReshaid, 2002).

\subsection{Students' learning engagement of instructional activity in engineering education}

In spite of the great interest in the multimedia to get learners' attention in the first place, relatively little evidence-base in the engineering education literature reveals its effect to support student learning with a focus on process and outcome. Various indicators and instruments that explore the concept of learning were examined and used in order to assess student learning, among them engagement refers to a student's psychological investment in, and effort directed toward, learning (Newmann, 1992). Students who are engaged with instructional activity are more likely to learn, to find the experience rewarding, to graduate, and to pursue higher education (Goodlad, 1984). Among a variety of indicators to learning, students' engagement is critical to student motivation during the learning process, and the motivation will then affect students' perception toward the 
materials, technologies and the overall instruction (Sutcliffe \& Faraday, 1994). While the motivating strategies involve different levels of engaging (Ryan \& Deci, 2000; Moller, Ryan \& Deci, 2006), engagement can be viewed as a promising indicator to represent student learning process and outcome. Previous studies in video-assisted instructions have documented the difficulties and struggles to evaluate specific use of video in real sense (Bracher, Collier, Ottewill, \& Shephard, 2005; Shephard, 2003). Due to the complexity involved in real educational settings and the nature of learning, it is not easy to precisely define any learning outcome to be affected by single media (Sung \& Mayer, 2012), let alone most videos were used in the context of blended learning (Garrison, 2001 Palmer, 2007; Shephard, 2003). Therefore to verify what would affect student learning, this study adopted several conditional reasons through the educational context of applying MAI in general engineering education and further explored the effects of student engagement in multimedia-assisted instruction and learning.

\section{Method}

\subsection{Context}

This study was implemented in a general engineering and technology education course entitled "Scientific Taiwan" offered by a research university in Northern Taiwan (See Fig. 1). The curriculum is specially designed for the foreign undergraduate students of various majors to learn about the general technological and industrial background of Taiwan. It is an elective course comprises 18 weeks of lectures, by 2 major instructors and 5 invited speakers from various disciplines at 4 universities and 4 research institutes in total. The contents covered significant achievements in the integrated circuit industry, display industry, computer and information technology industry, nano and biomedical technology, agriculture and ecological research, and traditional industry transformation development in Taiwan. Except for the 3 weeks of site visit, each week in the class meeting one or two technological topics were taught in lectures accompanied by a 30-minute multimedia video that presented relevant content to improve understanding of the issues (See Fig. 2). All of the video clips were pre-made by the instructors with English subtitles and Chinese narrations. After each class, these videos were streamed and posted on the course website for students to review anytime (See Fig. 3).

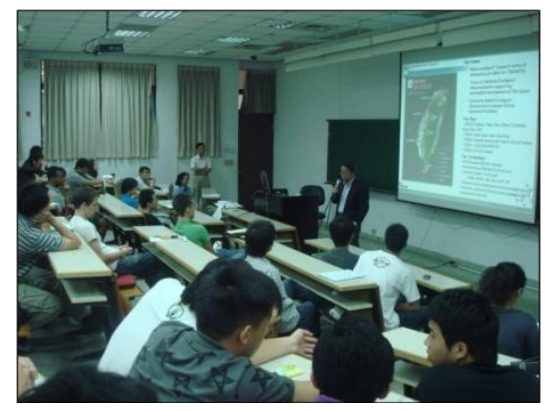

Fig. 1. The university general engineering education course designed for undergraduate students with a variety of nationalities 


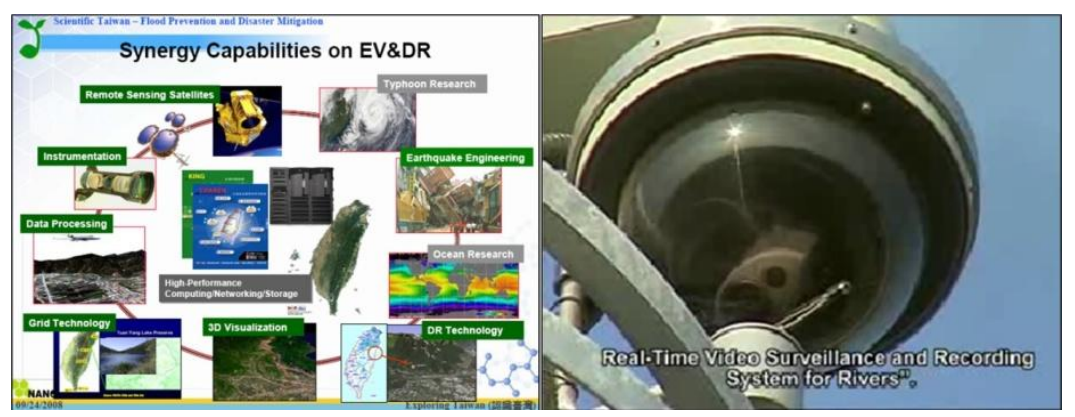

Fig. 2. Class meeting lecture and 30-minute multimedia video

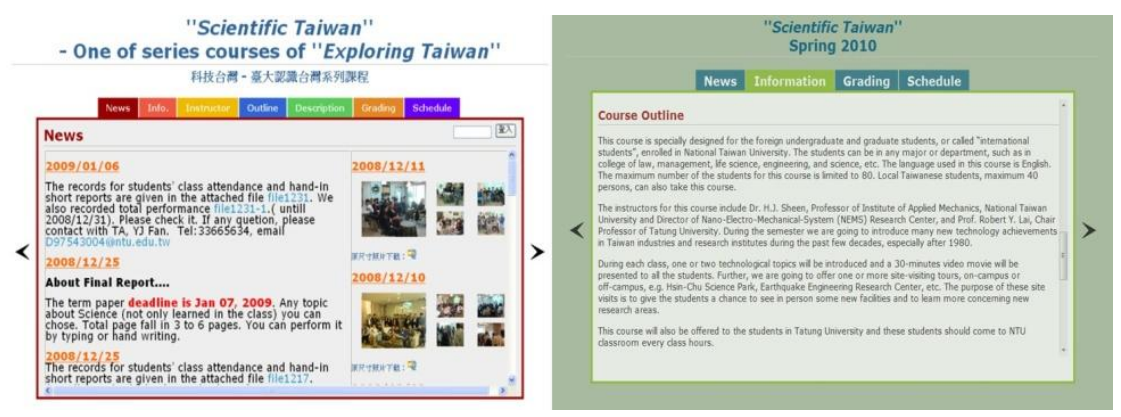

Fig. 3. The course website

\subsection{Instrument}

The researchers developed a questionnaire in order to investigate the effectiveness of applying multimedia in support of instruction and learning in this general engineering education course. The questionnaire comprised three sections: information on gender, nationality, and specialty; students' experience of watching multimedia videos in support of their learning; and students' attitude toward the multimedia-assisted learning application. For the attitude survey, a 6-point Likert-type scale from strongly disagree (1) to strongly agree (6) was adopted for evaluation (Grover \& Vriens, 2006). Based on a previous literature review, this study divided students into three learning groups according to their reasons for watching multimedia video after class. These students reporting autonomous reasons were defined as positive learners; those who reported heteronymous reasons were defined as passive learners; and those who never accessed the multimedia videos after class were categorized into the group of non-learning learners. To ensure the validity of measurement of engagement, subject matter experts of engineering education were invited to validate the instrument. Reliability of the instrument was also reasonably accepted (Cronbach's alpha $=0.954)$.

\section{Data collection and analysis}

The questionnaire was administered to all students in the final class meeting of the course. Descriptive and variance analysis were then conducted to understand the phenomenon of multimedia-assisted instruction. 


\section{Results}

\subsection{Subjects}

The subjects of this study were 54 undergraduate students registered in the general engineering education course entitled "Scientific Taiwan." The course is included in a special minor program, the "Taiwan Research Academic Program". Of the 54 subjects participating in this research with valid returns of questionnaires, 45 were males $(83.3 \%)$ and 9 were females (16.7\%). About one-third (17 students, 31.5\%) were foreign students from a variety of countries. Students registered in this course were from different departments with various majors; most of them were studying bio-resources and agriculture ( 22 students, $40.7 \%$ ), followed by public health (17 students, $31.5 \%$ ), law \& social science (14 students, 26.0\%), and engineering (5 students, 9.3\%), medicine (3 students, 5.6\%), liberal arts (3 students, 5.6\%) and science (1 student, 1.9\%) (Table 1).

Table 1

Background data of the participants ( $\mathrm{N}=54)$

\begin{tabular}{lcc}
\hline Variable & Frequency & Percentage \\
\hline Gender & & \\
Male & 45 & $83.3 \%$ \\
Female & 9 & $16.7 \%$ \\
Nationality & 37 & \\
$\quad$ Taiwanese & 17 & $68.5 \%$ \\
Other & & $31.5 \%$ \\
Specialty* & 22 & \\
Bio-Resource and Agriculture & 17 & $40.7 \%$ \\
Public health & 14 & $31.5 \%$ \\
Law \& Social Science & 5 & $26.0 \%$ \\
Engineering & 3 & $9.3 \%$ \\
Medicine & 3 & $5.6 \%$ \\
Liberal Art & 1 & $5.6 \%$ \\
Science & & $1.9 \%$ \\
\hline
\end{tabular}

*More than one response was acceptable

\subsection{Students' experiences of watching multimedia videos after class}

There were 17 students $(31.5 \%)$ who reported that they never watched the multimedia materials after class. For the other 37 students, the reasons they watched the multimedia videos after class included having to write class reports (44.4\%); being interested in the lecture topics $(27.8 \%)$; wanting to learn more $(20.4 \%)$; wanting to review the contents learned in class (9.3\%); and trying to catch up in the class (3.7\%). The researchers further sorted students by their learning engagement in terms of their multimedia video watching behavior, and categorized students into three groups: 13 students that actively wanted to learn more as positive learners; 24 students who just wanted to meet assigned requirements as passive learners; and those 17 students who never watched the multimedia videos after class as non-learning learners. The students were asked to identify the top three lecture topics that they had enjoyed the most after class. Results showed that the topics of videos students preferred most were wireless technology in Taiwan (44.4\%), nano education and core facilities (38.9\%), and aerospace technology and defense technology (35.2\%) (Table 2). 
Table 2

Students' experience of watching multimedia videos after class $(\mathrm{N}=54)$

\begin{tabular}{lcc}
\hline Variable & Frequency & Percentage \\
\hline Watching multimedia videos after class & 37 & $78.5 \%$ \\
Yes & 17 & $31.5 \%$ \\
No & & \\
Reasons for watching multimedia videos after class* & 24 & $44.4 \%$ \\
Have to write class reports & 15 & $27.8 \%$ \\
Interested in the lecture topics & 11 & $20.4 \%$ \\
To learn more information & 2 & $3.7 \%$ \\
Unable to follow the class & 5 & $9.3 \%$ \\
To review the contents learned in class & & \\
Learning engagement for watching multimedia videos & 13 & $24.1 \%$ \\
Positive learners & 24 & $44.4 \%$ \\
Passive learners & 17 & $31.5 \%$ \\
Non-learning learners & & \\
Top three preferred multimedia videos watched after & & \\
class* & 24 & $44.4 \%$ \\
Wireless Technology in Taiwan & 21 & $38.9 \%$ \\
Nano Education \& Core Facilities & 19 & $35.2 \%$ \\
Aerospace Technology \& Defense Technology & 15 & $27.8 \%$ \\
Eco-Grid of Taiwan & 14 & $25.9 \%$ \\
Flood Prevention and Disaster Mitigation & 14 & $25.9 \%$ \\
Digital Archives & 14 & $25.9 \%$ \\
Semiconductor Industry: SOC, NDL, ITRC & 20 & $21.5 \%$ \\
Light \& Electricity & 18 & $19.4 \%$ \\
Green Energy & 5 & $9.3 \%$ \\
Agriculture Technology \& Internet Medicare & &
\end{tabular}

*More than one response was acceptable

\subsection{Students' attitudes toward multimedia-assisted instruction}

While this study tried to investigate students' attitudes toward multimedia-assisted instruction, results showed that they perceived the multimedia video as able to improve their understanding of the content $(\mathrm{M}=5.19, \mathrm{SD}=1.01)$ and the depth of their learning $(\mathrm{M}=5.13, \mathrm{SD}=0.99)$ in this course. They also perceived the multimedia video as able to raise their awareness of learning issues in this area $(M=5.00, S . D=1.18)$. Students also reported their preference for multimedia-assisted learning. They liked this approach of using multimedia video to assist instruction and learning $(\mathrm{M}=5.17, \mathrm{SD}=1.077)$ and preferred this approach over traditional lecture-based instruction $(\mathrm{M}=5.19, \mathrm{SD}=1.011)$. Moreover, they would recommend this course to other students in the future $(M=4.93$, $\mathrm{SD}=1.226$ ). Results of students' attitudes toward multimedia-assisted instruction confirmed the effectiveness of using multimedia videos in support of instruction and learning in this general engineering education course. Also, students in the positive learner groups showed the highest levels of appreciation for multimedia-assisted instruction on all items (See Table3). 
Table 3

Attitudes toward multimedia-assisted instruction among the three learning groups

\begin{tabular}{|c|c|c|c|c|c|c|c|c|}
\hline \multirow[t]{2}{*}{ Items } & \multicolumn{2}{|c|}{$\begin{array}{l}\text { Positive } \\
\text { learner }\end{array}$} & \multicolumn{2}{|c|}{$\begin{array}{l}\text { Passive } \\
\text { learner }\end{array}$} & \multicolumn{2}{|c|}{$\begin{array}{l}\text { Non- } \\
\text { learning } \\
\text { learners }\end{array}$} & \multicolumn{2}{|c|}{ ALL } \\
\hline & $\mathrm{M}$ & S.D. & $\mathrm{M}$ & S.D. & $\mathrm{M}$ & S.D. & $\mathrm{M}$ & S.D. \\
\hline $\begin{array}{l}\text { improve understanding of } \\
\text { contents }\end{array}$ & 5.64 & 0.50 & 5.04 & 1.11 & 5.00 & 1.12 & 5.19 & 1.01 \\
\hline $\begin{array}{l}\text { arouse awareness of } \\
\text { learning issues }\end{array}$ & 5.50 & 0.78 & 4.87 & 1.46 & 4.76 & 1.09 & 5.00 & 1.18 \\
\hline $\begin{array}{l}\text { improve the depth of } \\
\text { learning }\end{array}$ & 5.64 & 0.50 & 5.09 & 0.66 & 4.76 & 1.15 & 5.13 & 0.99 \\
\hline $\begin{array}{l}\text { like multimedia to assist } \\
\text { instruction and learning } \\
\text { approach }\end{array}$ & 5.50 & 0.65 & 5.00 & 1.21 & 5.12 & 1.17 & 5.17 & 1.08 \\
\hline $\begin{array}{l}\text { multimedia is better than } \\
\text { traditional instruction }\end{array}$ & 5.50 & 0.65 & 5.09 & 1.08 & 5.06 & 1.14 & 5.19 & 1.01 \\
\hline $\begin{array}{l}\text { will recommend this } \\
\text { course to my classmates }\end{array}$ & 5.43 & 0.65 & 4.61 & 1.44 & 4.94 & 1.19 & 4.93 & 1.23 \\
\hline $\begin{array}{l}\text { This course motivates my } \\
\text { interests of learning. }\end{array}$ & 4.85 & 1.41 & 4.79 & 1.02 & 4.35 & 0.93 & 4.67 & 1.10 \\
\hline $\begin{array}{l}\text { Generally speaking, the } \\
\text { learning in this course is } \\
\text { meaningful and useful. }\end{array}$ & 4.77 & 1.17 & 4.63 & 1.01 & 4.65 & 1.12 & 4.67 & 1.06 \\
\hline $\begin{array}{l}\text { Generally speaking, this } \\
\text { is an effective course. }\end{array}$ & 4.77 & 1.42 & 4.75 & 1.07 & 4.41 & 0.87 & 4.65 & 1.10 \\
\hline
\end{tabular}

\subsection{Students' learning engagement on their attitudes towards multimedia- assisted learning}

Results of the study showed that positive learners $(M=5.54)$ had more positive attitudes toward multimedia-assisted learning than passive learners $(M=4.95)$ and those students who never watched the multimedia video after class $(M=4.94)$. In order to examine whether students' learning engagement in watching videos after class would have an impact on their attitudes toward multimedia-assisted learning, this study further conducted one-way ANOVA analysis at the 0.05 level to test the effect. Results revealed that some of the items did show significant differences among the three learning groups (positive, passive, and non-learning), indicating that this approach can improve the depth of their learning in this course.

To further examine the differences among the three groups, Schéffé's method was conducted as the post hoc comparison method. Results of analysis showed that the positive learning students of the former group had a greater perception of multimedia as able to improve the depth of their learning in this course than students who never watched multimedia videos after class (Table 4).

Also students' nationalities and their general attitudes toward the multimediaassisted learning were compared to learn if the narrative visualization help foreign student develop better comprehension. However, it was found that the domestic students generally made higher appraisal toward the video on their learning than foreign ones, albeit of no significant difference (Table 5). It was possibly due to the fact that the video clips were subtitled in English but narrated in Chinese, which might violate foreign 
students' learning styles, and resulted in the low appraisal toward the multimedia materials.

Table 4

ANOVA table for students' motivation on attitudes toward multimedia-assisted learning

\begin{tabular}{|c|c|c|c|c|c|c|}
\hline Items & Sources & $\mathrm{SS}$ & MS & $\mathrm{F}$ & $\mathrm{P}$ & $\begin{array}{l}\text { Post } \\
\text { hoc test }\end{array}$ \\
\hline \multirow{3}{*}{$\begin{array}{l}\text { improve } \\
\text { understanding of } \\
\text { contents }\end{array}$} & Between Groups & 3.977 & 1.989 & \multirow[t]{3}{*}{2.022} & \multirow[t]{3}{*}{0.143} & \\
\hline & Within Groups & 50.171 & 0.984 & & & \\
\hline & Total & 54.148 & & & & \\
\hline \multirow{3}{*}{$\begin{array}{l}\text { arouse awareness } \\
\text { of learning issues }\end{array}$} & Between Groups & 4.832 & 2.416 & \multirow[t]{3}{*}{1.782} & \multirow[t]{3}{*}{0.179} & \\
\hline & Within Groups & 69.168 & 1.356 & & & \\
\hline & Total & 74.000 & & & & \\
\hline \multirow{3}{*}{$\begin{array}{l}\text { improve the depth } \\
\text { of learning }\end{array}$} & Between Groups & 5.993 & 2.997 & \multirow[t]{3}{*}{3.315} & \multirow[t]{3}{*}{$0.044 *$} & \\
\hline & Within Groups & 46.099 & 0.904 & & & $\begin{array}{l}\text { Positive } \\
>\text { None }\end{array}$ \\
\hline & Total & 52.093 & & & & \\
\hline \multirow{3}{*}{$\begin{array}{l}\text { like multimedia } \\
\text { to assist } \\
\text { instruction and } \\
\text { learning approach }\end{array}$} & Between Groups & 2.235 & 1.118 & \multirow[t]{3}{*}{0.962} & \multirow[t]{3}{*}{0.389} & \\
\hline & Within Groups & 59.265 & 1.162 & & & \\
\hline & Total & 61.500 & & & & \\
\hline \multirow{3}{*}{$\begin{array}{l}\text { multimedia is } \\
\text { better than } \\
\text { traditional } \\
\text { instruction }\end{array}$} & Between Groups & 1.881 & 0.940 & \multirow[t]{3}{*}{0.918} & \multirow[t]{3}{*}{0.406} & \\
\hline & Within Groups & 52.267 & 1.025 & & & \\
\hline & Total & 54.148 & & & & \\
\hline \multirow{3}{*}{$\begin{array}{l}\text { will recommend } \\
\text { this course to my } \\
\text { classmates }\end{array}$} & Between Groups & 5.856 & 2.928 & \multirow[t]{3}{*}{2.022} & \multirow[t]{3}{*}{0.143} & \\
\hline & Within Groups & 73.848 & 1.448 & & & \\
\hline & Total & 79.704 & & & & \\
\hline
\end{tabular}

$* \mathrm{p}<0.05$

Table 5

Comparison between domestic and foreign students' attitude toward multimedia-assisted learning

\begin{tabular}{lcccc}
\hline & Domestic & \multicolumn{2}{c}{ Foreign } \\
\hline & Means & S.D. & Means & S.D. \\
\hline This course motivates my interests of learning. & 4.68 & 0.94 & 4.65 & 1.41 \\
$\begin{array}{l}\text { Generally speaking, the learning in this course is meaningful } \\
\text { and useful. }\end{array}$ & 4.68 & 0.92 & 4.65 & 1.37 \\
Generally speaking, this is an effective course. & 4.76 & 0.93 & 4.41 & 1.42 \\
\hline improve understanding of contents & 5.27 & 0.90 & 5.00 & 1.23 \\
arouse awareness of learning issues & 5.11 & 0.97 & 4.76 & 1.56 \\
improve the depth of learning & 5.14 & 1.00 & 5.12 & 0.99 \\
like multimedia to assist instruction and learning approach & 5.27 & 0.99 & 4.94 & 1.25 \\
multimedia is better than traditional instruction & 5.24 & 0.90 & 5.06 & 1.25 \\
will recommend this course to my classmates & 5.08 & 0.95 & 4.59 & 1.66 \\
\hline * $<0.05$ & & & &
\end{tabular}




\section{Conclusions}

This study intended to explore the effectiveness of applying multimedia in a general engineering and technology education course in support of students' learning. Results showed that students thought the multimedia could help them to improve their learning in general and in specific learning issues, which also confirmed the previous literature (Cairncross \& Mannion, 1999; Giannotti \& Galletti, 1996; Höhne \& Henkel, 2004; Kartam \& Al-Reshaid, 2002; Mutharasan et al., 1997), which indicated that applying multimedia to assist learning could help students to learn the materials. The introductory course introduced the technology and science developments in Taiwan, such as the integrated circuit industry, display industry, computer and information technology industry, nano and biomedical technology, agriculture and ecological research, and traditional industry transformation development. The three topics that the students showed the highest preference for were "Wireless Technology in Taiwan", "Nano Education and Core Facilities", and "Aerospace technology and defense technology". According to Badran (1995), multimedia materials should raise learners' awareness in certain aspects. The preference for related issues might lead students to further study on those issues in their later academic study. As for the effectiveness of applying multimedia materials in support of their learning, the students all liked this MAI approach, and preferred this approach over traditional instruction. Students also stated that it would increase their willingness to recommend this course to peers.

With further analysis, this study also found that students' degree of learning engagement caused variance in their perception of the helpfulness of multimedia-assisted learning in the course. Students who would actively review multimedia videos after class showed higher appreciation for this multimedia-assisted instruction. It would confirm the previous literature that the more students are motivated to learn, the more likely they are to perceive the effectiveness of instructional technology (Hunt et al., 2001; Kikuchi \& Kenjo, 1996; Maby et al., 1997; Nortcliffe \& Middleton, 2008; Sutcliffe \& Faraday, 1994). The results of this study also showed, based on different degrees of learning engagement, a significant difference among the three groups in how much multimedia video could help improve their learning. The researchers therefore propose that engineering educators should be aware of the effect of positive student engagement on attitude toward learning, and should design more complementary learning activities such as multimedia assisted instruction, online learning assignment as well as collaborative teamwork assignments, which would help engagement students more in deeper learning.

As a case study, albeit important results were found and confirmed by this study, it should be noticed that within limited time and ethical approval to collect student data after class, the qualitative inputs of students were not included in the current study. It might result in a narrowing of the generalizability of the study, however it did highlight the need of future work when undertaking education research. It is suggested that except for focusing on the specific concept of learning effectiveness such as engagement in this study, future studies could include both qualitative and quantitative evaluations to reveal better empirical evidence that show students' characteristics in learning with multimedia, such as learning styles, abilities, and language proficiency, especially for a hybrid class of international students. It is expected that the results of this study should contribute to both engineering and technology education practice and future research. 


\section{Acknowledgements}

The work described in this paper was supported by a grant from Taiwan's National Science Council (NSC 97-2515-S-002-010; NSC 98-2120-S-002-002-NM).

\section{References}

Badran, A. (1995). Promoting clean technology through the use of multimedia learning material in environmental engineering. European Journal of Engineering Education, 20(2), 183-185.

Bengu, G., \& Swart, W. (1996). A computer-aided, total quality approach to manufacturing education in engineering. IEEE Transactions on Education, 39(3), 415-422.

Boman, J., \& Olsson, M. (1996). A multimedia guide to the information jungle. European Journal of Engineering Education, 21(3), 229-234.

Bourne, J., Harris, D., \& Mayadas, F. (2005). Online engineering education: Learning anywhere, anytime. Journal of Engineering Education, 94(1), 15-41.

Bracher, M., Collier, R., Ottewill, R., \& Shephard, K. (2005). Accessing and engaging with video streams for educational purposes: experiences, issues and concerns. Research in Learning Technology, 13(2), 139-150.

Bringslid, O. (1999). Multimedia books in the mathematical education of engineers. European Journal of Engineering Education, 24(2), 189-199.

Cairncross, S., \& Mannion, M. (1999). How multimedia functions in engineering education. Engineering Science \& Education Journal, 8(3), 100-106.

Felder, R. M., \& Silverman, L. K. (1988). Learning and teaching styles in engineering education. Engineering Education, 78(7), 674-681.

Garrison, W. (2001). Video streaming into the mainstream. Journal of Audiovisual Media in Medicine, 24(4), 174-178.

Giannotti, E., \& Galletti, C. (1996). An approach based on simulation and hypermedia technology to a new courseware in mechanics of machines. European Journal of Engineering Education, 21(3), 229-234.

Goodlad, J. I. (1984). A place called school: Prospects for the future. New York: McGraw-Hill.

Grover, R., \& Vriens, M. (2006). The handbook of marketing research: Uses, misuses and future advances. SAGE Publications, Inc.

Höhne, G., \& Henkel, V. (2004). Application of multimedia in engineering design education. European Journal of Engineering Education, 29(1), 87-96.

Hunt, A., Howard, D. M., Kirk, R., Ash, K., \& Tyrrell, A. M. (2001). Interactive multimedia systems for engineering education in acoustics, synthesis and signal processing. European Journal of Engineering Education, 26(2), 91-106.

Kartam, N., \& Al-Reshaid, K. (2002). Design and implementation of web-based multimedia techniques for construction education. International Journal of Engineering Education, 18(6), 682-696.

Kikuchi, T., \& Kenjo, T. (1996). Developing multimedia training materials for use with small robot controls at Chubu polytechnic center in Japan. IEEE Transactions on Education, 39(3), 349-356.

Lang, J. D., Cruse, S., McVey, F. D., \& McMasters, J. (1999). Industry expectations of new engineers: A survey to assist curriculum designers. Journal of Engineering Education, 88(1), 43-51.

Laurillard, D. (2002). Rethinking university teaching. London: Routledge.

Maby, E. W., Carlson, A. B., Connor, K. A., Jennings, W. C., \& Schoch, P. M. (1997). A 
studio format for innovative pedagogy in circuits and electronics. Proceedings of the 27th Annual Frontiers in Education Conference: Teaching and Learning in an Era of Change, 3, 1431-1434.

Mahajan, A., McDonald, D., \& Walworth, M. (1996). General engineering education for non-engineering students. Proceedings of the 26th Annual Frontiers in Education Conference, 3, 1264-1266.

Marx, R. D., \& Frost, P. J. (1998). Toward optimal use of video in management education: examing the evidence. Journal of Management Development, 17(4), 243250.

Mayer, R. E. (2001). Multimedia learning. New York: Cambridge University Press.

Mitchell, D. (2001). Digitizing video. The Journal of Physical Education, Recreation and Dance, 72(4), 11-16.

Moller, A. C., Ryan, R. M., \& Deci, E. L. (2006). Self-determination theory and public policy: Improving the quality of consumer decisions without using coercion. Journal of Public Policy \& Marketing, 25(1), 104-116.

Mutharasan, R., Magee, W., Wheatley, M., \& Lee, Y. (1997). Multimedia assisted instruction in upper level engineering courses. Proceedings of the 26th Annual Frontiers in Education Conference, 3, 1175-1178.

Newmann, F. M. (1992). Student engagement and achievement in American secondary schools. New York: Teachers College Press.

Nortcliffe, A., \& Middleton, A. (2008). A three year case study of using audio to blend the engineer's learning environment. Engineering Education, 3(2), 45-52.

Palmer, S. (2007). An evaluation of streaming digital video resources in on- and offcampus engineering management education. Computers \& Education, 49(2007), 297308.

Raju, P. K., Sankarz, C. S., \& Xue, Y. (2004). A curriculum to enhance decision-making skills of technical personnel working in teams. European Journal of Engineering Education, 29(3), 437-450.

Ryan, R. M., \& Deci, E. L. (2000). Intrinsic and extrinsic motivation: Classic definitions and new directions. Contemporary Educational Psychology, 25, 54-67.

Schodorf, J. B., Yoder, M. A., \& McClellan, H. (1996). Using multimedia to teach the theory of digital multimedia signals. IEEE Transactions on Education, 39(3), 336341.

Shephard, K. (2003). Questioning, promoting and evaluating the use of streaming video to support student learning. British Journal of Educational Technology, 34(3), 295308.

Sutcliffe, A. G., \& Faraday, P. (1994). Designing presentation in multimedia interfaces. Proceedings of the SIGCHI conference on Human factors in computing systems: celebrating interdependence, 92-98.

Sung, E., \& Mayer, R.E. (2012). When graphics improve liking but not learning from online lessons. Computers in Human Behavior, 28(5), 1618-1625.

Teo, Y. H., \& Chai, C. S. (2009). Scaffolding online collaborative critiquing for educational video production. Knowledge Management \& E-Learning: An International Journal, 1(1), 51-66.

Wishart, J., \& Blease, D. (1999). Theories underlying perceived changes in teaching and learning after installing a computer network in a secondary school. British Journal of Educational Technology, 30(1), 25-41.

Yueh, H.-P., \& Sheen, H.-J. (2009). Developing experiential learning with a cohort blended laboratory training in nano-bio engineering education. International Journal of Engineering Education, 25(4), 712-722. 